\title{
URANIUM PARTITIONING IN KIMBERLITES AND THEIR DEEP-SEATED INCLUSIONS •
}

\author{
J. D. KLEEMAN ${ }^{*}$ AND J.F. LOVERING ${ }^{*}$
}

* Department of Geology, University of New England, Armidale, N.S.W., Australia.

* School of Geology, University of Melbourne, Parkville, Victoria, Australia.

Fission track "Lexan" print studies of kimberlites and their associated suites of deep-seated inclusions are reported from localities in South Africa, Tanzania, Sierre Leone, Kentucky and Siberia.

Kimberlites have been shown previously by Morgan and Lovering (1971) to have relatively high uranium (1.05 $3.97 \mathrm{ppm} \mathrm{U})$ and thorium $(4.3-25.3 \mathrm{ppm} \mathrm{Th})$ abundances with Th/U ratios averaging 4.8 and ranging from 4.1 to 7.1 . The "primary" kimberlite phases are highly depleted in uranium (garnet $<3$ ppbU, olivine $<0.2$ ppbU, orthopyroxene $<0.5 \mathrm{ppbU}$, ilmenite $<1 \mathrm{ppbU})$. On the basis of a Ucpx/Uopx partition coefficient of $\sim 7$, and Ucpx/ULiquid partition coefficient of $\sim 0.0012$, then the U content or orthropyroxene in kimberlites is characteristic of equilibrium with a silicate liquid containing < 3 ppmU. This is a value well within the observed range of $U$ abundances in kimberlites. The typically fine-grained matrix of kimberlite, usually consisting largely of hydrated silicates and calcite, is relatively enriched in uranium ( 0.2 to $1 \mathrm{ppm}$ ) although the specifically "secondary" kimberlite phases, such as phlogopite (< $10 \mathrm{ppb} \mathrm{U})$ and calcite $(<10 \mathrm{ppb} \mathrm{U})$, are not enriched in uranium. The highest uranium abundances are observed in secondary perovskite ( $>23 \mathrm{ppm} U$ ) which commonly partly replaces ilmenite in most kimberlites studied. The only kimberlite studied which did not contain perovskite (i.e. from Siberia) also showed similarly U-enrichments around altered ilmenite grains. Apparently uranium is mobilised during late-stage "hydrothermal" activity in the kimberlite matrix and deposited in phases formed at the interface of "primary" ilmenite grains during this activity.

Granulite and amphibolite inclusions, possibly derived from lower crustal sources, have been studied from kimberlites from South Africa and Kentucky. In the granulites, some uranium is located along grain boundaries and probably represents addition of U-rich hydrothermal fluids from the kimberlite matrix. However the major contributions are found in minor "primary" phases such as zircon (< 20 ppm and $>200 \mathrm{ppm} U)$, rutile $(18 \mathrm{ppm}, 50 \mathrm{ppm} \mathrm{U})$ and apatite (1.8 $2.5 \mathrm{ppm} U)$ while the major primary phases are relatively depleted in uranium. The amphibolites show some uranium along grain boundaries but the major contribution of uranium is located in the amphibole $(\sim 0.32-0.43 \mathrm{ppm})$ and in accessory 
apatites (15 - $52 \mathrm{ppm}$ and 37 - 100 ppm).

The other inclusions (e.g. eclogites, garnet peridotites etc.) are of possible upper mantle origin. The primary phase in the eclogities are depleted in uranium with garnet ranging from $1-3 \mathrm{ppb} U$ and clinopyroxene from $0.8-82$. ppb $U$ and most of the uranium reported in the rock (see Morgan and Lovering 1971) is found along grain boundary alteration zones and has apparently been added from the kimberlite matrix. The primary clinopyroxenes have U contents consistent with crystallization from magmas ranging in U content from 0.6 to $6.8 \mathrm{ppm} \mathrm{U}$. This range is broad and could be consistent with equilibration with basic magmas or with kimberlites.

In the garnet peridotite inclusion the garnet contains moderate $U$ abundances $(2-140 \mathrm{ppb})$, clinopyroxene from 7 to $30 \mathrm{ppb}$, orthopyroxenes from $<1$ to $7.2 \mathrm{ppb}$ and olivine < 0.3 $\mathrm{ppb}$. There are no uranium-enriched phases in these rocks and most of the uranium is located along grain boundaries as in the eclogite inclusions. The clinopyroxenes have U contents consistent with equilibration with magmas containing $5.8 \mathrm{ppm}$ to $25 \mathrm{ppm} U$ and generally well outside the range of either basaltic or kimberlitic types. A similar (though even more extreme) anomaly was reported by Kleeman et al. (1968) for some primary clinopyroxenes in lherzolite nodules from Victorian alkali basalt. If current estimates of Ucpx/ ULiquid distribution coefficients are correct, then many of these ultramafic inclusions must have formed in association with a special vapour or fluid phase relatively enriched in uranium and have not subsequently been subject to removal of basaltic liquids by partial melting processes. 